\title{
COST - BENEFIT ANALYSIS FOR NIGERIAN NATURAL GAS PIPELINE INVESTMENT
}

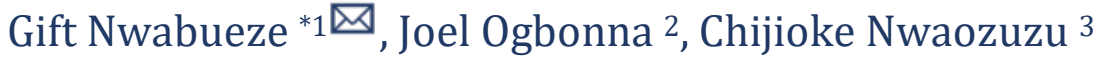 \\ ${ }^{*} 1,3$ Emerald Energy Institute, University of Port-Harcourt, Nigeria \\ 2 World bank Center of Excellence for Oilfield Chemicals Research, University of Port-Harcourt, \\ Nigeria
}

DOI: https://doi.org/10.29121/ijetmr.v7.i9.2020.780

Article Citation: Gift Nwabueze, Joel Ogbonna, and Chijioke Nwaozuzu. (2020). COST - BENEFIT ANALYSIS FOR NIGERIAN NATURAL GAS PIPELINE INVESTMENT. International Journal of Engineering Technologies and Management Research, 7(9), 52-65. https://doi.org/10.29121/ijetmr.v7 i9.2020.780

Published Date: 25 September 2020

Keywords:

Gas Pipeline

Cost-Benefit Analysis

Investment

Net Present Value

Payback

Nigeria

\section{ABSTRACT}

This paper performs cost-benefit analysis of a pipeline infrastructure project based on a given natural gas demand in order to estimate the net present value and payback time for natural gas pipeline investment in Nigeria. The result of the cost-benefit analysis indicates a positive net revenue and net present value (NPV) at the current regulated transport cost and availability factor for gas pipelines in Nigeria. However, with a payback period of 14 years, a natural gas pipeline project in Nigeria is likely to lose-out investment capital to other competing investments within the oil and gas sector. Scenario analysis indicates that by doubling the regulated transport cost with a 50\% tax reduction, the pipeline investment results in a much higher NPV and a payback of 4 years, which is more acceptable to investors.

\section{INTRODUCTION}

Globally, the natural gas industry is experiencing increasing competition by suppliers in the international market leading to very low international gas prices. Most countries are now looking out for the renewable energy option, making the market power to gradually shift from producers to buyers. In Nigeria, factors such as; militancy in the Niger Delta, inadequacy of transportation infrastructure and delay in completion time for on-going projects leads to inadequate supply of natural gas. Others issues such as governance, legislation and regulatory issues are part of the challenges that affect the growth of the Nigerian natural gas industry.

The current laws governing the gas sector were made for oil production and not gas, with several regulatory institutions having conflicting roles and no clearly defined boundaries. The presence of unpaid cash calls for the joint venture arrangements have also made it extremely onerous to attract foreign direct investment in the sector. Shell, a major player in the Nigerian oil and gas industry have identified absence of pipeline infrastructure, inadequate regulatory, commercial and legal framework and non-adherence to contractual obligations as some of the factors bedeviling the development of natural gas in the country. 
Cost - Benefit Analysis for Nigerian Natural Gas Pipeline Investment

The infrastructure blueprint of the Nigerian Gas Master Plan outlined some of the infrastructure needed to address the infrastructural challenge of the Nigerian gas industry such as existing gas pipeline networks expansion, building new pipeline networks covering the eastern, western, northern parts and construction of gas processing facilities in the Niger Delta region for processing the produced gas for onward supply to transportation networks and other industrial hubs and plants.

The National gas policy (NGP) also was approved in 2017 to drive regulatory reforms and set up institutional changes for the attraction of investors in the natural gas sector. The policy seeks to ensure open access to pipeline networks and other midstream infrastructure to all players in the natural gas market through the use of the required network code.

Under the NGP, gas infrastructure has been classified into; Existing gas infrastructure, Gas Master Plan Infrastructure Blueprint, New gas transportation links, Upgrading Nigerian Gas Processing and Transportation Company network, Alternative gas transportation options, Key anchor customer infrastructure (e.g Ajaokuta Kaduna Kano pipeline project), Distribution infrastructure, Security of gas supply investment (additional infrastructure for robustness of network), Resource clusters and Identification of critical gas infrastructure.

Finally, a major variance from the NGMP is that the NGP is designed to identify natural gas resources and natural gas resource clusters and critical infrastructure needed in order to prioritize developments. The Nigerian Gas Processing and Transmission Company (NGPTC) and Ministry of Petroleum Resources (MPR) are empowered by this policy to monitor and issue licenses to private investors who desire to pursue a potentially beneficial natural gas project which may not be stated in the blueprint. This paper carries-out cost-benefit analysis of hypothetical pipeline infrastructure project based on an estimated natural gas demand in order to estimate the net present value and payback time for natural gas pipeline investment in Nigeria.

\subsection{CONCEPTUAL FRAMEWORK}

Natural gas pipeline is the best in terms of cost effectiveness when natural gas is to be transported over a long distance. Natural gas transportation system may be a complex network of pipelines and other facilities with primary aim of supplying natural gas from the demand center to the required region. Pipelines can be classified as gathering system, transmission and distribution systems (Naturalgas.org, 2013). The gathering system functions to transport raw natural gas from the point of production (wellhead) to the processing station. Natural gas transmission network is defined as a high-pressure pipeline system that transmits natural gas from suppliers or processing stations to distribution stations over long distance using large diameter pipelines. While a natural gas distribution system takes natural gas from the transmission system at lower pressures and distributes it to the various consumers using smaller diameter pipelines.

Natural gas pipelines can be further classified based on the network topologies. A linear topology refers to a linear arrangement of pipes and compressor stations. The tree topology refers to an arrangement in branches while a cyclic topology refers to compressors and pipes being arranged in cycles with other stations (Mah and Shacham, 1978). Frictional forces between the walls of the pipeline and the gas results in pressure drop as natural gas flows across the pipeline. As a result, compressor stations are located and installed at strategic points to increase the pressure of the gas and ensure that it is received at the required pressure at the demand center.

Compressor stations are referred to as pumping stations and it consist of scrubber, compressor unit, cooling unit computerized flow system control, and emergency shutdown system (EIA, 2007). The compressor stations are normally powered by gas turbines which use part of the transported gas for power generation therefore most designs are done to minimize the quantity of transport gas consumed by the turbine or lost to friction in the pipeline network.

The Nigerian gas sector has had operational pipelines in the country since the early 1960s when gas was discovered. The existing pipeline network and infrastructure is insufficient to supply gas for the need of the entire country and this creates vulnerability in the country's energy sector due to the role that is played by the pipeline infrastructure (Biose, 2019). Among the gas pipeline project listed in the infrastructure blueprint of the NGMP nearly $590 \mathrm{~km}$ of these gas pipelines have been commissioned while others are still in various completion stages. See list below.

Oben-Geregu (196km), Expansion of Escravos-Warri-Oben $(110 \mathrm{~km})$, Emuren-Itoki $(50 \mathrm{~km})$, Itoki-Olorunshogo (31km), Imo River-Alaoji (24km), Ukanafun-Calabar (128km), Aba-Owerri-Nnewi-Onitsha Pipeline Project, East- 
West OB3 pipeline (127km), Expansion of the Escravos-Lagos Gas Pipeline System, NOPL (50km), Trans Nigeria Gas Pipeline $(1400 \mathrm{~km})$, Calabar-Ajaokuta Pipeline $(614 \mathrm{~km})$, Ajaokuta-Kaduna-Kano (AKK) Pipeline Project, ELPIbadan-Jebba Pipeline Project, Obiafu-Obrikom-Oben (OB3) Pipeline Project, Expansion of ELP Phase 2 Project, Erha / Bosi Pipeline Project, Oso Platform to QIT Pipeline Project, West African Gas Pipeline project (678Km).

\subsubsection{TRANS NIGERIA GAS PIPELINE PROJECT}

The TNGP is one of the gas pipeline projects conceived in the infrastructure blueprint of the Nigerian Gas Policy and it consist of a $1300 \mathrm{~km}$ long pipeline system with diameters ranging from 36 inches to 40 inches. It is planned to run from Qua Iboe Terminal via the Obigbo-Umuahia-Enugu-Ajaokuta network to the Ajaokuta-Abuja-Kaduna-Kano (AKK) network (Global Energy Monitor, 2020).

The project will consist of three main phases.

1) The Ajaokuta - Kaduna - Kano (AKK) pipeline which transports natural gas from Ajaokuta through Abuja to Kaduna up to Kano.

2) The Qua Iboe terminal including Cawthorne channel / Alakiri and a metering station in Obiafu / Obrikom.

3) The third section is proposed to be laid from Obigbo gas compressor station to Ajaokuta.

The phase one of the project is the Ajaokuta-Kaduna-Kano pipeline which is to originate in Ajaokuta, passing through Kaduna and terminate at Kano. Gas will be supplied from various gas gathering stations and the pipeline will terminate at a gas processing station in Kano. The pipeline will provide gas to cement factories, compressed natural gas (CNG) users, gas power plants, residential users and other industrial/ manufacturing companies in the northern part of Nigeria. TNGP proposes to transport 11 to $24 \mathrm{MMscfd}$ of natural gas and this will form a part of the larger Trans Sahara Gas Pipeline system which plans to transport natural gas from Nigeria to Algeria. The construction cost is $\$ 2.8$ Billion (Global Energy Monitor, 2020).

\subsubsection{WEST AFRICAN GAS PIPELINE PROJECT (WAGP)}

Article 48 of Economic Community of West African States (ECOWAS) encourages member states to consult, cooperate and co-ordinate policies with regards to energy and mineral resources. The WAGP in line with ECOWAS article 48 was formed by a treaty entered into by the Federal Republic of Nigeria, Republic of Benin, Republic of Ghana and Togo with the objective of supplying gas from Nigeria to Ghana, Benin and Togo via pipeline network (Federal Republic of Nigeria Official Gazette, 2005).

The 678-kilometer gas pipeline system links an existing Escravos to Lagos pipeline to Ghana with laterals extending to Cotonou, Lome and Tema (Ghana). The WAGP will initially transport 170MMscfd of gas and eventually get to a peak capacity of $460 \mathrm{MMscfd}$. The main line has a diameter of 20 inches while the laterals to Cotonou and Lome has 8 inches diameter. The extension to Tema has a diameter of 18 inches. 85\% of the gas transported in WAGP is for power generation in the various nations, while the remaining $15 \%$ is for industrial applications.

\subsection{THEORY OF INVESTMENT MODELING}

Maurice Clark, as early as 1917, postulated that investment decision is based on the increasing demand for output rather than the level of demand. This Accelerator mechanism theory, as it was referred to, gained the support of the Keynesian revolution and this development greatly contributed to microeconomic advancement. The Keynesian methodology more specifically refers to the expected profitability and how it relates to the concept of marginal capital efficiency.

R. F. Harrod in 1936 suggested that interest rate, capital - output ratio, technology and confidence level were the main factors affecting investment decision. He implied that incremental change in capital stock (change in investment) is driven by changes in output. Jorgenson in 1963 refined this statement to read that investment decisions are made when the relative cost of capital is equal to the marginal productivity of the capital. The CobbDouglas production function provides a veritable platform for the expansion of these theories. 
The simple accelerator theory model states that "flows into the stock of capital by business occur whenever expectations for output demand increase". Therefore, increase in investment is a function of increase in demand in that sector.

$$
\begin{aligned}
& K_{t}=h Y_{t} \\
& K_{t-1}=h Y_{t-1} \\
& I_{t}=K_{t}-K_{t-1}=h\left(Y_{t}-Y_{t-1}\right)
\end{aligned}
$$

Where: $I_{t}=$ Net Investment, $K_{t}=$ Investment (or Capital stock), $Y_{t}=$ Expected output,

$h=$ Capital/ Output ratio.

The Jorgenson's investment model in conjunction with Fisher's model forms the main premise for the modern neoclassical approach to the investment theory. This postulate states that the optimum capital stock is reached where the expected benefit from an additional unit of output are equal. That is;

$$
M C=M R
$$

Where $M C=$ Marginal cost, $M R=$ Marginal revenue.

By utilizing the Cobb-Douglas production function, that is;

$$
Y=A K^{\alpha}{ }^{\beta}
$$

Where: $\mathrm{Y}=$ Output, $\mathrm{A}=$ Constant, $\mathrm{K}=$ Capital, $\mathrm{L}=$ Labour, $\alpha=$ Elasticity of output with respect to Capital, $\beta=$ Elasticity of output with respect to Labour.

The Jorgenson's model can be represented as:

$$
\frac{\partial Y}{\partial K}=\alpha K^{\alpha-1} L^{\beta}=\alpha \frac{Y}{K}
$$

The optimal point is reached at a point where the marginal product of capital is equal to the relative cost of capital. That is;

$$
\alpha \frac{Y}{k^{\text {optimum }}}=C
$$

Where $\mathrm{C}=$ Cost of capital.

Therefore,

$$
K^{\text {optimum }}=\alpha Y / C
$$

This implies that investment is a function of change in the ratio of output to capital.

\subsection{METHODS OF MAKING INVESTMENT DECISIONS}

Investors often face the dilemma of having to choose from various available investment options and the best choice is made in order to align with organization's goals. Generally, changes in market conditions are inevitable and it is the job of firms to adapt to these changes in order to meet market demands. Investment is one way the firm 
curbs the effect of constant market changes. Every investment possesses certain level of risk and good decision process ensures that all potential risk scenarios are put in perspective through adequate feasibility studies.

Feasibility study involves the estimation of investment parameters such as Net Present Value (NPV), Internal Rate of Return (IRR), Payback period etc. Puska et al (2017) defines two methods of carrying out feasibility studies. The Static method, involving pre-investment studies and the results represents the outcome for a given year. Economic indicators such as Pay-back period, NPV, IRR, Modified IRR and Profitability index can be estimated with the static method while the Dynamic method accesses the investment and the effect of the investment over the whole project life. This method allows for a much more realistic analysis of the different aspects of the investment project. These techniques finds application in most project approval process and their estimation form a major part of investment feasibility study. They are usually based on a discounted cash flow (DCF) principle and the output depends on the accuracy of the cash flow predictions as well as other assumptions which contains substantial uncertainty inherently.

Mohammed and McCowan (1999) noted that the above-mentioned technique do not allow for non-monetary (qualitative) factors which introduces considerable levels of risks and uncertainty into the project appraisal process. They include; social, environmental, political and legal factors. Two of the most commonly used risk analysis techniques were identified as Sensitivity analysis and Probability analysis. Sensitivity analysis models the impact of change in chosen variables on the IRR in order to identify factors that are highly risk sensitive while the probabilistic analysis uses a more sophisticated method such as Monte Carlo simulations to model the combined effect of multiple risk factors according to their relative frequencies. The right specification of probability to each risk factor is crucial to the accuracy of the estimate. They developed a computer program using possibility theory that combines both monetary and non-monetary aspects of a project's economic viability. The tool used was Excel and Visual Basics Applications (VBA). Their proposed methodology was capable of effectively modeling both monetary and nonmonetary factors affecting investment decision making.

More recent studies in investment analysis involve multi-criteria analysis which requires that several alternatives be considered by maximizing some of them and minimizing the others. Puska et al (2017) highlighted the Simple Additive method (SAM), Topsis method and Vikor method of multi-criteria investment selection analysis. SAM involves attaching weights to each criteria and choosing the investment that results in the highest value while Topsis method selects the investment with the shortest distance from the positive ideal solution and the longest distance from the negative ideal solution. In Vikor method, the decision maker proposes a solution that represents a compromise between different interest in the decision-making process. Investors generally choose the method that minimizes the investment risks.

Alexiou (2014) developed an econometric model for the investment behavior of selected countries using data covering a period of 10 years. A financial development variable was inserted into Accelerator theory model in order to improve the explanatory power of the model.

That is:

$$
I_{t}^{\text {accelerator }}=a+\sum \beta_{n} Y_{t-n}+\sum Y_{n} C U_{t-n}+(\partial-1) C S_{t-1}+\mathfrak{I} f d_{t-1}+\varepsilon_{t}
$$

Where: $I_{t}=\log$ of gross investment; $Y_{t}=\log$ of output; $C S_{t}=$ Natural log of capital stock $C U=$ Capital utilization; $f d_{t}=$ Proxy for financial development; $\varepsilon_{t}=$ Error term; $\quad \partial=$ Depreciation rate; $a=$ Intercept; $\beta, \mathfrak{I}=$ Slope of coefficients.

Lags were also inserted to capture the delayed effects of decisions over investment activity. Econometric testing for unit roots was done using Augmented Dickey Fuller (ADF) test while the model was specified using Auto Regressive Distribution Lag (ARDL). The first observation was that the model result behaved differently for different countries. That is, investment decisions were found to be very complex given different economic structure and everchanging economic environment, thus indicating the presence of huge uncertainties that must be considered for individual climes. Also, the econometric model appears to be at odds with underlying investment theories.

Finally, Lovric et al (2008) explores how investors make investment decisions in the real world setting rather than proposed investment decision methods by financial theories for a rational mind. They narrowed investors attitude down to seven (7) different attributes; 1- the investors preferences and risk attitude. 2- Portfolio allocation 
Cost - Benefit Analysis for Nigerian Natural Gas Pipeline Investment

in practice, diversification in practice and the influence of various constraints. 3- Portfolio management, performance measurement and employed strategies. 4- Information processing and learning. 5- Social interactions and peer influence. 6- The role of emotions and intuition. 7- Heuristics, biases and departures from rationality. They concluded that the investment process is driven by a dual mental process (Cognitive and Affective) and the resulting interplay between these two systems contributes to a bounded rational behavior which manifests itself through various heuristics and biases.

\subsection{LITERATURE REVIEW}

Shang $\mathrm{Hu}$ and Klaiber (2019) examined the impact of new large-scale natural gas pipeline construction on emissions reduction and fuel consumption in China. Much of the energy consumption expansion that resulted in rapid economic growth for China previously relied on coal which is a dominant energy resource in China. However, a decision was reached by policy makers recently to embark on the construction of large-scale natural gas pipeline infrastructure with a goal of enhancing access to natural gas resources by local communities and newly developing regions. They used difference-in-difference method to study the impact of natural gas pipeline investment on household and industrial choices of energy resource type. The result of the difference- in- difference estimate shows that investment in pipeline infrastructure reduced significantly the emissions intensity by enhancing natural gas consumption and reducing coal consumption and intensity in the industrial sector.

Perrotten and Massol (2018) also studied the microeconomic classification of relationship between input and output level for a point to point gas pipeline system comprising of a compressor station, injecting a pressurized flow of natural gas into a the pipeline in order to contribute to the economic regulation of natural gas pipelines. They converted engineering equations governing a gas pipeline infrastructure into a Cobb-Douglas production function. The resulting equation was used to show that the long run function of the economic function for a pipeline infrastructure verifies the condition for a natural monopoly, justifying the need for proper regulation of the natural gas sector. In the short run, their analysis reveals that the average transportation cost incurred in an existing pipeline can be lowered by expanding output level up to a threshold level representing $110 \%$ of the output that was considered during the pipeline design and construction. Confirming that the short run marginal pricing scheme cannot guarantee capital cost recovery by pipeline operator if output is lower than the threshold level. Finally, the research revealed that the rate of return regulation that leads to maximum net social welfare can be larger than the market price of capital when the demand price elasticity is low.

Demissie et al (2017) studied and developed mathematical models for linear, branched and looped network topologies while considering both minimization of power consumption and maximization of gas delivery flow rate for a natural gas pipeline. The decision variables considered were pressure at the nodes and rotational speed of the compressor station. The study was a non-linear programming problem due to the non-linearity of the objectives and constraints. They classified optimization problems generally as either design optimization (referring to the selection of material sizes and layout within the pipeline system) or operation optimization problem (referring to existing networks and station configuration). They presented the natural gas pipeline operation as a multi criterion decision making process in which an optimal solution represents the optimal operating condition between the high flow rate requirement and the low power consumption interest for the different network systems and types. The optimization of the model was done using NSGA II algorithm and jMetal - an object-oriented JAVA based program. They observed that the higher the compression ratio, the higher the power demand on the compressor. This implies that lower compression ratio requires more compressor stations along the pipeline hence more cost, and also, higher flowrate requires more power at higher speed of compressor.

Oster and Dilavenglu (2014) developed a decision support system that will aid decision makers in optimizing natural gas transmission networks. It is expected that with increasing demand, the size and complexity of pipeline network should increase to meet the demand at new customer nodes. They employed a Mixed Integer Non-linear model to determine the location and size of compressor stations, nature of pipelines, timing of installation, quantity of gas to supply and pressure requirements, so as to minimize the total investment cost and operating cost of installing the transmission pipeline system. The Total cost of the pipeline installation was defined as:

Total cost $=$ Investment cost + operating cost of pipeline + Investment cost + operating cost of compressor station + Natural gas purchase cost + Transportation cost. 
Gas transportation cost was assumed to depend on the gas flow rate in the pipelines and classified as operating cost. The investment cost per unit length included labour, material, installation and right of way cost, which depends on the length and diameter of the pipeline. Compressor cost was also assumed to vary with the installed power. The solution to the optimization problem helps to make informed decision on the location, capacity of the compressor station, new pipelines and network type that minimizes total cost. They observed, by varying the cost, that transportation cost was the most influential in changes to total costs. Their cost optimization model shows that models built with high transport cost and pipeline cost tends to delay the installation decisions while adjusting flow and purchasing quantities to trade off overall cost efficiency.

Pierru et al (2013) provides empirical insight into the capital structure of project financed gas pipelines and LNG infrastructures. Data for the capital structure from 26 related natural gas infrastructure projects for different countries occurring between 2004 and 2011 were analyzed. The identified determinants of debt to capital investment ratios were; Type of infrastructure, Country risk, Ownership concentration, Project size, Post crisis and Project expansion. Projects located in risky countries and larger projects generally showed lower debt ratios and lower concentration of equity ownership. Projects located in a non-risky country with large number of sponsors (diluted equity) will have a high debt ratio (about 0.94). Re-gasification projects tend to exhibit more diluted equity ownership. Also, the more risky a country where the project is located is, the lower the project debt ratio and the more concentrated the equity ownership, the lower the debt ratio. In their regression model, they found that all these determinants were significant at $5 \%$ confidence level. Finally there result showed that among the 26 projects studied in different countries, Nigeria, with a risk rating of 6.0, had the least debt ratio (about 0.24 for the Accugas pipeline project) with a capital investment cost of about 250 million dollars.

Finally, Adamu and Darma (2017) carried out an economic analysis on proposed gas pipeline projects in Nigeria as listed in the Nigerian Gas Master Plan (2008). The planned pipeline routes were analysed according to existing economic models for investment decision indicators such Net Present value (NPV), Internal rate of return (IRR), Payback period and Investment cost model. They represented the initial investment cost for the chosen pipeline project as follows:

Initial Investment cost $\mathrm{C} 0=\mathrm{E}(\mathrm{CCP})+\mathrm{E}(\mathrm{CCMS})$

Where; $\mathrm{E}(\mathrm{CCP})=$ Expected pipeline construction and laying cost;

$\mathrm{E}(\mathrm{CCM})=$ Expected cost of installing compressor stations.

Therefore,

$$
\mathrm{NPV}=-\mathrm{C} 0+\mathrm{C} 1 /(1+\mathrm{r})+\mathrm{C} 2 /(1+\mathrm{r})^{2}+\ldots \ldots .+\mathrm{Cr} /(1+\mathrm{r})^{\mathrm{r}}
$$

Where; $\mathrm{C} 0=$ Initial Investment cost and $\mathrm{Cr}=$ Net Cash flow for the respective periods.

And $r=$ Discount rate.

Their analysis identified the BSRO pipeline route as the most viable option among the six planned gas pipeline routes in the NGMP because it presented the route with the highest NPV value and ranked highest in terms of profitability.

\section{MATERIALS AND METHOD}

This section describes the necessary assumptions for the economic analysis of a natural gas pipeline project in order to ascertain the project viability and profitability at predicted or forecasted natural gas consumption levels. This analysis will be based on the general equation by Adamu and Darma (2017) thus;

\subsection{INITIAL INVESTMENT COST (IIC)} $\mathrm{E}(\mathrm{CCS})$

IIC = Expected cost of construction and Laying down pipeline (ECCP) + Cost of Installing compressor station 
Where,

$\mathrm{E}(\mathrm{CCP})=$ Gas pipeline material cost $(\mathrm{PMC})+$ Pipe coating and wrapping cost $(\mathrm{PCW})+$ Labour cost $(\mathrm{LC})$

Where, $\quad$ PCW $=5 \% *$ PMC

And,

$$
P M C=0.0246(D-T) \text { TLC }
$$

Where, $\quad \mathrm{T}=$ Wall thickness $(\mathrm{mm})$ and $\mathrm{C}=$ Pipe material cost $(\$ /$ metric ton $)$

\subsection{LABOUR COST}

Labour cost for any pipeline project varies based on the location and the installation environment/ contractor. Using international labour charge as a base for this work,

$$
\text { LC }=\$ 15000 * \text { Diameter (in) * Length (miles) }
$$

\subsection{COMPRESSOR STATION}

The minimum interval for installation of compressor station is 64 to $161 \mathrm{~km}$ from the injection/ pressure point. Hence,

$\mathrm{E}(\mathrm{CCS})=\$ 2000 *$ Horse Power $*$ Number of compressors

\subsection{PIPELINE THICKNESS}

The following equation will suffice for pipe thickness;

Thickness $=($ Outside diameter - Inside diameter $) / 2$

\subsection{DEPRECIATION AND TAXATION}

- Straight line depreciation method is assumed

Tax benefit $=$ Tax rate ${ }^{*}$ Annual depreciation value (Assuming salvage value is zero)

\subsection{OPERATING AND MAINTENANCE COST}

- Assumed as $2 \%$ of investment cost

\subsection{COST OF CAPITAL}

The capital structure can be assumed as $60 / 40$ debt to equity ratio, in line with the capital structure for an average oil and gas company operating in Nigeria.

Capital Asset Pricing Model (CAPM) is adopted for the estimation of cost of equity while After tax cost of debt will measure the cost of debt for this project. The Weighted Average Cost of Capital (WACC) has been adopted to calculate the project's discount rate from the debt and equity contribution thus;

$$
\mathrm{WACC}=\frac{E}{C} * K e+\frac{D}{C} * K d(1-T R)
$$

Where, $\mathrm{C}=$ Total value of capital, $\mathrm{D}=$ Total value of debt, $\mathrm{E}=$ Total value of equity, $\mathrm{Ke}=$ Cost of equity, $\mathrm{Kd}=\mathrm{Cost}$ of debt, $\mathrm{TR}=$ Tax rate $(30 \%$ in Nigeria $)$ 
$\mathrm{Kd}=\mathrm{r}^{*}(1-\mathrm{TR})$

Where, $r=$ Prime lending rate for commercial banks in Nigeria $=17 \%$ (2019)

$\mathrm{Ke}=\mathrm{rf}+\beta(\mathrm{rm}-\mathrm{rf})$

Where, $\mathrm{rf}=$ Risk free interest rate, $\mathrm{rm}=$ Market portfolio return, $(\mathrm{rm}-\mathrm{rf})=$ risk premium $=6.75($ World bank, 2016)

$\beta$ is the reaction of the price share of a business to a change in the stock market $=0.86$

\subsection{AMORTIZATION COST}

Amortization cost $=\frac{\text { Debt } * \text { Interest rate }}{1-\left(\frac{1}{1+\text { interest rate }}\right)^{n}}$

Where, $\mathrm{n}=$ Total number of period.

\subsection{PIPELINE CAPACITY / VOLUME OF GAS}

Weymouth formula is used for its estimation. Thus,

$$
\mathrm{Q}=\frac{871 d^{8 / 3}}{\sqrt{L}} \sqrt{\left(P 1^{2}-P 2^{2}\right)}
$$

Where, $Q=$ Cubic feet of gas / 24 hours,

$\mathrm{d}=$ Inside diameter

$\mathrm{P} 1$ = Starting pressure

P2 = Ending pressure

$\mathrm{L}=$ Length of pipe in miles.

\subsection{REGULATED TRANSPORT COST}

In Nigeria the regulated transport cost for gas pipeline transportation is fixed at $\$ 0.8$ / mcf irrespective of the distance. Availability rate of $80 \%$ is applied in this work; this is based on the average availability of existing pipeline infrastructure in Nigeria.

\subsection{NET PRESENT VALUE (NPV) AND INTERNAL RATE OF RETURN (IRR)}

NPV = the difference between the investment cost and the sum of the present value of the future value of all cash flows.

IRR = the discount rate at which the business breaks even. That is the discount rate at which NPV $=0$.

\section{RESULTS AND DISCUSSIONS}

\subsection{ASSUMPTIONS}

- $\quad$ Nigerian natural gas demand $=400$ bcf/year

- The Outside diameter of the proposed pipeline $=56 "$

- $\quad$ Pipe wall thickness $=0.5 "$

- Cost of Steel $=\$ 800 /$ mton 
- Compressor stations is installed at $100 \mathrm{~km}$ interval

- $\quad$ Compressor horse power $=5000 \mathrm{Hp}$

- $\quad$ Starting Pressure =870.24 Psi

- $\quad$ End Pressure = 580.16 Psi

- Number of years of pipeline operation $=40$ years

\subsection{REVENUE DATA}

- Total length of Pipeline required to transport $400 \mathrm{bcf}$ daily = 20, $256 \mathrm{~km}$

- $\quad$ Pipeline capacity $=0.66 \mathrm{bcf} / \mathrm{d}$

- $\quad$ Pipe delivery capacity $=0.529 \mathrm{bcf} / \mathrm{d}$

- $\quad$ Pipeline transport cost $=\$ 0.81 / \mathrm{mcf}$

- Availability factor $=80 \%$

- Annual Revenue from Pipeline Investment = \$428,410,031.37

\subsection{COST DATA}

- $\quad$ Pipeline Material cost PMC $=\$ 11,062,313.74$

- $\quad$ Pipeline Coating and Wrapping $=\$ 553,115.69$

- $\quad$ Labour cost $=\$ 1,174,049,118.36$

- $\quad$ Operation and Maintenance cost $=\$ 64,225,682.89$

- Compressor Station Installation cost $=\$ 2,025,619,596.90$

- Total Pipeline Installation cost IIC = \$ 3,211,284,144.69

\subsection{FISCAL REGULATIONS}

- $\quad$ Corporate tax rate $=15 \%$

- $\quad$ Straight line depreciation $=\$ 80,282,103.62$

- $\quad$ Annual Tax Benefit $=\$ 24,084,631.09$

- $\quad$ Cost of Debt $=\$ 1,926,770,486.82$

- $\quad$ Cost of Equity $=\$ 1,284,513,657.88$

- Weighted Average Cost of Capital (Discount Rate) $=16.15 \%$

- $\quad$ Prime Lending rate (Interest Rate) $=17.00$

- Amortisation $=\$ 8,188,774.57$

\subsection{NET PRESENT VALUE TABLE}

\begin{tabular}{|c|c|c|c|c|c|}
\hline Year & Cost & Revenue & $\begin{array}{c}\text { Cumulative Cash } \\
\text { flow }\end{array}$ & Net Cash flow & $\begin{array}{l}\text { Discounted Cash } \\
\text { flow }\end{array}$ \\
\hline 0 & $\begin{array}{c}- \\
\$ 6,107,862,443.2 \\
1\end{array}$ & 0 & & $\begin{array}{c}- \\
\$ 6,107,862,443.21\end{array}$ & $-\$ 6,107,862,443.21$ \\
\hline 1 & & $\begin{array}{c}\$ 452,494,662.4 \\
6\end{array}$ & $\$ 452,494,662.46$ & $\begin{array}{c}- \\
\$ 5,655,367,780.75\end{array}$ & $-\$ 4,869,020,904.65$ \\
\hline 2 & & $\begin{array}{c}\$ 452,494,662.4 \\
6\end{array}$ & $\$ 904,989,324.92$ & $\begin{array}{c}- \\
\$ 5,202,873,118.29\end{array}$ & $-\$ 3,856,601,862.70$ \\
\hline 3 & & $\begin{array}{c}\$ 452,494,662.4 \\
6 \\
\end{array}$ & $\$ 1,357,483,987.38$ & $\begin{array}{c}- \\
\$ 4,750,378,455.83\end{array}$ & $-\$ 3,031,590,714.66$ \\
\hline 4 & & $\begin{array}{c}\$ 452,494,662.4 \\
6\end{array}$ & $\$ 1,809,978,649.84$ & $\begin{array}{c}- \\
\$ 4,297,883,793.37\end{array}$ & $-\$ 2,361,444,876.66$ \\
\hline
\end{tabular}


Gift Nwabueze, Joel Ogbonna, and Chijioke Nwaozuzu

\begin{tabular}{|c|c|c|c|c|}
\hline 5 & $\begin{array}{c}\$ 452,494,662.4 \\
6\end{array}$ & $\$ 2,262,473,312.30$ & $\begin{array}{c}- \\
\$ 3,845,389,130.91\end{array}$ & $-\$ 1,819,048,270.64$ \\
\hline 6 & $\begin{array}{c}\$ 452,494,662.4 \\
6\end{array}$ & $\$ 2,714,967,974.75$ & $\begin{array}{c}- \\
\$ 3,392,894,468.46\end{array}$ & $-\$ 1,381,831,430.99$ \\
\hline 7 & $\begin{array}{c}\$ 452,494,662.4 \\
6\end{array}$ & $\$ 3,167,462,637.21$ & $\begin{array}{c}- \\
\$ 2,940,399,806.00\end{array}$ & $-\$ 1,031,031,387.11$ \\
\hline 8 & $\begin{array}{c}\$ 452,494,662.4 \\
6\end{array}$ & $\$ 3,619,957,299.67$ & $\$ 2,487,905,143.54$ & $-\$ 751,069,463.17$ \\
\hline 9 & $\begin{array}{c}\$ 452,494,662.4 \\
6\end{array}$ & $\$ 4,072,451,962.13$ & $\begin{array}{c}- \\
\$ 2,035,410,481.08\end{array}$ & $-\$ 529,028,512.40$ \\
\hline 10 & $\begin{array}{c}\$ 452,494,662.4 \\
6 \\
\end{array}$ & $\$ 4,524,946,624.59$ & $\$ 1,582,915,818.62$ & $-\$ 354,213,963.71$ \\
\hline 11 & $\begin{array}{c}\$ 452,494,662.4 \\
6\end{array}$ & $\$ 4,977,441,287.05$ & $\$ 1,130,421,156.16$ & $-\$ 217,785,479.94$ \\
\hline 12 & $\begin{array}{c}\$ 452,494,662.4 \\
6\end{array}$ & $\$ 5,429,935,949.51$ & $-\$ 677,926,493.70$ & $-\$ 112,448,078.08$ \\
\hline 13 & $\begin{array}{c}\$ 452,494,662.4 \\
6\end{array}$ & $\$ 5,882,430,611.97$ & $-\$ 225,431,831.24$ & $-\$ 32,193,296.92$ \\
\hline 14 & $\begin{array}{c}\$ 452,494,662.4 \\
6\end{array}$ & $\$ 6,334,925,274.43$ & $\$ 227,062,831.22$ & $\$ 27,917,533.81$ \\
\hline 15 & $\begin{array}{c}\$ 452,494,662.4 \\
6\end{array}$ & $\$ 6,787,419,936.89$ & $\$ 679,557,493.68$ & $\$ 71,934,626.65$ \\
\hline 16 & $\begin{array}{c}\$ 452,494,662.4 \\
6 \\
\end{array}$ & $\$ 7,239,914,599.34$ & $\$ 1,132,052,156.14$ & $\$ 103,171,325.46$ \\
\hline 17 & $\begin{array}{c}\$ 452,494,662.4 \\
6\end{array}$ & $\$ 7,692,409,261.80$ & $\$ 1,584,546,818.59$ & $\$ 124,330,716.23$ \\
\hline 18 & $\begin{array}{c}\$ 452,494,662.4 \\
6\end{array}$ & $\$ 8,144,903,924.26$ & $\$ 2,037,041,481.05$ & $\$ 137,611,274.88$ \\
\hline 19 & $\begin{array}{c}\$ 452,494,662.4 \\
6\end{array}$ & $\$ 8,597,398,586.72$ & $\$ 2,489,536,143.51$ & $\$ 144,794,933.98$ \\
\hline 20 & $\begin{array}{c}\$ 452,494,662.4 \\
6\end{array}$ & $\$ 9,049,893,249.18$ & $\$ 2,942,030,805.97$ & $\$ 147,320,414.86$ \\
\hline 21 & $\begin{array}{c}\$ 452,494,662.4 \\
6\end{array}$ & $\$ 9,502,387,911.64$ & $\$ 3,394,525,468.43$ & $\$ 146,344,220.11$ \\
\hline 22 & $\begin{array}{c}\$ 452,494,662.4 \\
6\end{array}$ & $\$ 9,954,882,574.10$ & $\$ 3,847,020,130.89$ & $\$ 142,791,300.13$ \\
\hline 23 & $\begin{array}{c}\$ 452,494,662.4 \\
6 \\
\end{array}$ & $\$ 10,407,377,236.56$ & $\$ 4,299,514,793.35$ & $\$ 137,397,086.12$ \\
\hline 24 & $\begin{array}{c}\$ 452,494,662.4 \\
6\end{array}$ & $\$ 10,859,871,899.02$ & $\$ 4,752,009,455.81$ & $\$ 130,742,310.88$ \\
\hline 25 & $\begin{array}{c}\$ 452,494,662.4 \\
6\end{array}$ & $\$ 11,312,366,561.48$ & $\$ 5,204,504,118.27$ & $\$ 123,281,810.32$ \\
\hline 26 & $\begin{array}{c}\$ 452,494,662.4 \\
6\end{array}$ & $\$ 11,764,861,223.93$ & $\$ 5,656,998,780.73$ & $\$ 115,368,306.49$ \\
\hline 27 & $\begin{array}{c}\$ 452,494,662.4 \\
6\end{array}$ & $\$ 12,217,355,886.39$ & $\$ 6,109,493,443.18$ & $\$ 107,272,010.77$ \\
\hline 28 & $\begin{array}{c}\$ 452,494,662.4 \\
6\end{array}$ & $\$ 12,669,850,548.85$ & $\$ 6,561,988,105.64$ & $\$ 99,196,749.89$ \\
\hline 29 & $\begin{array}{c}\$ 452,494,662.4 \\
6 \\
\end{array}$ & $\$ 13,122,345,211.31$ & $\$ 7,014,482,768.10$ & $\$ 91,293,202.63$ \\
\hline
\end{tabular}


Cost - Benefit Analysis for Nigerian Natural Gas Pipeline Investment

\begin{tabular}{|c|c|c|c|c|}
\hline 30 & $\begin{array}{c}\$ 452,494,662.4 \\
6 \\
\end{array}$ & $\$ 13,574,839,873.77$ & $\$ 7,466,977,430.56$ & $\$ 83,669,739.06$ \\
\hline 31 & $\begin{array}{c}\$ 452,494,662.4 \\
6\end{array}$ & $\$ 14,027,334,536.23$ & $\$ 7,919,472,093.02$ & $\$ 76,401,272.94$ \\
\hline 32 & $\begin{array}{c}\$ 452,494,662.4 \\
6\end{array}$ & $\$ 14,479,829,198.69$ & $\$ 8,371,966,755.48$ & $\$ 69,536,470.43$ \\
\hline 33 & $\begin{array}{c}\$ 452,494,662.4 \\
6 \\
\end{array}$ & $\$ 14,932,323,861.15$ & $\$ 8,824,461,417.94$ & $\$ 63,103,600.89$ \\
\hline 34 & $\begin{array}{c}\$ 452,494,662.4 \\
6\end{array}$ & $\$ 15,384,818,523.61$ & $\$ 9,276,956,080.40$ & $\$ 57,115,268.12$ \\
\hline 35 & $\begin{array}{c}\$ 452,494,662.4 \\
6 \\
\end{array}$ & $\$ 15,837,313,186.07$ & $\$ 9,729,450,742.86$ & $\$ 51,572,220.27$ \\
\hline 36 & $\begin{array}{c}\$ 452,494,662.4 \\
6\end{array}$ & $\$ 16,289,807,848.52$ & $\begin{array}{c}\$ 10,181,945,405.3 \\
2\end{array}$ & $\$ 46,466,403.05$ \\
\hline 37 & $\begin{array}{c}\$ 452,494,662.4 \\
6\end{array}$ & $\$ 16,742,302,510.98$ & $\begin{array}{c}\$ 10,634,440,067.7 \\
7\end{array}$ & $\$ 41,783,393.12$ \\
\hline 38 & $\begin{array}{c}\$ 452,494,662.4 \\
6\end{array}$ & $\$ 17,194,797,173.44$ & $\begin{array}{c}\$ 11,086,934,730.2 \\
3\end{array}$ & $\$ 37,504,325.01$ \\
\hline 39 & $\begin{array}{c}\$ 452,494,662.4 \\
6 \\
\end{array}$ & $\$ 17,647,291,835.90$ & $\begin{array}{c}\$ 11,539,429,392.6 \\
9 \\
\end{array}$ & $\$ 33,607,405.25$ \\
\hline 40 & $\begin{array}{c}\$ 452,494,662.4 \\
6 \\
\end{array}$ & $\$ 18,099,786,498.36$ & $\begin{array}{c}\$ 11,991,924,055.1 \\
5 \\
\end{array}$ & $\$ 30,069,091.32$ \\
\hline 41 & & $\$ 18,099,786,498.36$ & $\begin{array}{c}\$ 11,991,924,055.1 \\
5\end{array}$ & $\$ 25,888,154.39$ \\
\hline
\end{tabular}

\subsection{SCENARIO ANALYSIS RESULT}

Table 3.2: Normal investment outcome scenario.

\begin{tabular}{|c|c|c|c|}
\hline SENSITIVITIES & RATE & Net Revenue & NPV \\
\hline TAX RATE & $100 \%$ & $\$ 8,394,346,838.61$ & $\$ 23,808,399.23$ \\
\hline PIPELINE TRANSPORT COST & $100 \%$ & $\$ 8,394,346,838.61$ & $\$ 23,808,399.23$ \\
\hline AVAILABILITY FACTOR & $100 \%$ & $\$ 8,394,346,838.61$ & $\$ 23,808,399.23$ \\
\hline NATURAL GAS CONSUMPTION & $100 \%$ & $\$ 8,394,346,838.61$ & $\$ 23,808,399.23$ \\
\hline
\end{tabular}

Table 3.3: Double Pipeline transport cost.

\begin{tabular}{|c|c|c|c|}
\hline SENSITIVITIES & RATE & Net Revenue & NPV \\
\hline TAX RATE & $100 \%$ & $\$ 20,389,827,717.07$ & $\$ 60,802,446.16$ \\
\hline PIPELINE TRANSPORT COST & $200 \%$ & $\$ 20,389,827,717.07$ & $\$ 60,802,446.16$ \\
\hline AVAILABILITY FACTOR & $100 \%$ & $\$ 20,389,827,717.07$ & $\$ 60,802,446.16$ \\
\hline NATURAL GAS CONSUMPTION & $100 \%$ & $\$ 20,389,827,717.07$ & $\$ 60,802,446.16$ \\
\hline
\end{tabular}

Table 3.4: Double Pipeline transport cost with 50\% reduction in tax rate.

\begin{tabular}{|c|c|c|c|}
\hline SENSITIVITIES & RATE & Net Revenue & NPV \\
\hline TAX RATE & $50 \%$ & $\$ 24,759,076,513.59$ & $\$ 60,802,446.16$ \\
\hline PIPELINE TRANSPORT COST & $200 \%$ & $\$ 24,759,076,513.59$ & $\$ 60,802,446.16$ \\
\hline AVAILABILITY FACTOR & $100 \%$ & $\$ 24,759,076,513.59$ & $\$ 60,802,446.16$ \\
\hline NATURAL GAS CONSUMPTION & $100 \%$ & $\$ 24,759,076,513.59$ & $\$ 60,802,446.16$ \\
\hline
\end{tabular}




\subsection{DISCUSSION OF FINDINGS}

The Nigerian natural gas demand data suggests that natural gas demand is an average of $400 \mathrm{bcf} / \mathrm{y}$ (approximately). This volume resulted in a gas pipeline length of 20,256 km from geometric estimations. The total length of gas pipeline in Nigeria today is below $3000 \mathrm{~km}$. This presents a huge gap between the required length of gas pipeline to meet the expected natural gas demand in Nigeria and the actual pipeline infrastructure on the ground.

The investment yield from the economic analysis for the proposed gas pipeline project results in a positive net revenue and net present value (NPV). However, this NPV is not substantial enough to attract investors into the Nigerian natural gas sector in a competitive international market. The estimated Pay-out time from the DCF calculation is approximately 14 years of the initial investment and this time period is a set-back as other investments competing for capital may pay back at shorter time (i.e., less than 5 years)

The scenario analysis conducted shows that the main factor responsible for the extended payback time or reduced NPV is the regulated transport cost for gas pipeline transportation in Nigeria, which is fixed at $\$ 0.8 / \mathrm{mcf}$, irrespective of the length of the gas pipeline. Increased length of gas pipeline means increased installation cost of the pipeline required for the transportation of a fixed volume of gas. This implies reduced revenue and thus extended pay-back time.

In the double pipeline transport cost scenario (table 4.4), there is an increase in net revenue by $\$ 12$ billion and increase in the net present value by about $\$ 40$ million due to a $100 \%$ increase in the regulated transport cost while still assuming that the cost is fixed for the entire $20,256 \mathrm{~km}$ length of gas pipeline. The West African Gas pipeline project (WAGP) has a length of $678 \mathrm{~km}$ and natural gas transport cost for this pipeline should not cost the same as $20,000 \mathrm{~km}$ of gas pipeline. This makes the assumption in this scenario very modest.

The Double Pipeline transport cost with 50\% reduction in tax rate (table 4.5) scenario also lead to an increase of additional $\$ 4$ billion in net revenue from the double pipeline transport cost scenario and a payback period of 4 years for the gas pipeline investment. This shows that incentives such as tax reduction or relief can significantly enhance the profitability of investors and this can enhance the private participation in the Nigerian natural gas pipeline sector.

\section{CONCLUSIONS AND RECOMMENDATIONS}

From the analysis, the current network of gas pipeline is insufficient to cater for the current and future natural gas demand in Nigeria. Investments in natural gas pipeline will enhance socio-economic growth and standard of living of Nigerians but the right gas pipeline transportation cost and fiscal incentives is needed to enhance private or foreign investment in this sector. From the above findings, the following recommendations can be made

1) The regulated transport cost for gas pipeline should be adjusted to reflect current economic reality. This will encourage investors to invest in natural gas pipeline construction.

2) Fiscal incentives such as tax reliefs and other policy regulations, which can spur investment in the Nigerian natural gas pipeline sector, are needed.

3) Studies to determine appropriate model of pricing for the regulated transport cost for gas pipeline is recommended.

\section{SOURCES OF FUNDING}

None.

\section{CONFLICT OF INTEREST}

None. 
Cost - Benefit Analysis for Nigerian Natural Gas Pipeline Investment

\section{ACKNOWLEDGMENT}

This research is sponsored by the Petroleum Technology Development Fund, Nigeria.

I also hereby acknowledge the support I received from the management and staff of Emerald Energy Institute in course of this research in graduate school.

\section{REFERENCES}

[1] Adamu, A., Darma, M., (2017). Economic Analysis of Gas Pipeline Projects in Nigeria. Journal of economics and sustainable development, 8(2).

[2] Alexiou, C., (2014). Modeling Investment Behavior: Emerging Evidence, https//www.researchgate.net/publication/266677632

[3] Biose, H., (2019). Gas Pipelines in Nigeria: Sine Qua Non for Economic Development, International Journal of Engineering Technologies and Management https://core.ac.uk/download/pdf/211976549.pdf

[4] Clark, J.M. (1917). Business Acceleration and the Law of Demand: A Technical Factor in Economic Cycles, Journal of Political Economy 25(1): 217-35

[5] Demissie, A., Zhu, W., Taye, C., (2017). A Multi-objective Optimization Model for Gas Pipeline, Computers and chemical engineering, http://dx.doi.org:10.1016/j.compchemeng.2017.02.01

[6] Federal Republic of Nigeria Official Gazette, (2005). West African Gas Pipeline Project Act 2005, 92(67) A181 $-227$.

[7] Global Energy Monitor. (2020). Trans Nigeria Gas Pipeline, https://www.gem.wiki/Trans_Nigeria_Gas_Pipeline

[8] Harrod, R.F. (1936). The Trade Cycle, Oxford: Oxford University Press

[9] Jorgenson, D.W. (1963). Capital Theory and Investment Behavior, American Economic Review, 53, 247-59.

[10] Lovric, M., Kaymak, U., Spronk, J., (2008). A Conceptual Model of Investor Behavior. ERIM report series research in management, http//hdl.handle.net/1765/12468

[11] Mah, R., Shacham, M., (1978). Pipeline Network Design and Synthesis, Advances in Chemical Engineering, 10, 125-209, https://www.sciencedirect.com/science/article/pii/S0065237708601337

[12] Mohamed, S., McCowan, A., (2001). Modeling Project Investment Decisions under Uncertainty Using Probability Theory, International journal of project management 19 (2001) 231-241.

[13] Naturalgas.org, (2013). The Transportation of Natural gas, http://naturalgas.org/naturalgas/transport/

[14] Organisation of Oil Producing and Exporting Countries OPEC, (2018). Nigeria facts and figures, https://www.opec.org/opec_web/en/about_us/167.htm

[15] Perrotton, F., Massol, O., (2018). The technology and cost structure of a natural gas pipeline: Insights for costs and rate-of-return regulation, Utilities policy, 53(2018) 32 - 37.

[16] Pierru, A., Roussanaly, S., and Sabathier, J., (2013). Capital structure in LNG infrastructure and gas pipeline projects: Empirical evidence and methodolical issues, Energy policy, 61(2013) 285 - 291.

[17] Puska, A., Beganovic, A., and Sadic, S., (2018). Model for Investment Decision Making by Applying the MultiCriteria Analysis Method, Serbian Journal of Management, 13(1) (2018) 7 - 28.

[18] Shang Xu, H., Klaiber, A., (2019). The Impact of New Natural Gas Pipelines on Emissions and Fuel Consumption in China, Resource and Energy Economics, 55(2019) 49 - 62. http:// www.sciencedirect.com

[19] Shell, (2017). Natural gas, https://www.shell.com.ng/media/nigeria-reports-and-publications-briefingnotes/potential-in-natural-gas.html

[20] Uster, H., Dilaveroglu, S., (2014). Optimisation for Design and Operation of Natural Gas Transmission Networks, Applied Energy, 133(2014) 56-69.

[21] United States Energy Information Administration, (2008). U.S. Natural Gas Imports and Exports: 2007, https://www.eia.gov/naturalgas/importsexports/annual/archives/2009/ngimpexp07.pdf 